\title{
MIDWIFE AND NURSE STUDENTS' PERCEPTIONS OF BODY PRIVACY AND SELF ESTEEM. THE CASE OF TURKEY
}

\author{
Gün Mukadder ${ }^{1}$, Aslantekin Özçoban Filiz ${ }^{2}$
}

\begin{abstract}
The article reports the results of a study conducted to examine midwifery and nursing students' perceptions of body intimacy and the factors affecting their perceptions. This was a cross-sectional study, with 389 midwifery and nursing students at a public university volunteering to participate in the study. Data were collected using a "Personal Information Form", the "Body Confidentiality Scale for Obstetrics and Gynecology" and the "Rosenberg Self-Esteem Scale". The participants had a mean age of $20.89 \pm 1.86$ years. The mean score they gave to the question whether they paid attention to privacy was $8.21 \pm 1.88$. The mean Rosenberg self-esteem score was $29.44 \pm 4.83($ minimum $=10$, maximum $=40)$. The mean overall privacy score was $36.10 \pm 6.84$ $(\min =9, \max =45)$, rights and privacy was $20.80 \pm 3.71(\min =5, \max =25)$, ethics and privacy was $20.45 \pm 3.67(\min =5$, $\max$ $=25)$, and clinical privacy was $75.22 \pm 12.33(\min =18, \max =90)$. According to the results, obstetrics and nursing students, who would later intervene in women's health, had higher than average self-esteem and perception of privacy. Nevertheless, the establishment of the concept of "privacy" is an issue that should be addressed and reinforced in the training of obstetrics and nursing students who will provide services in such a sensitive field as gynecology and obstetrics.
\end{abstract}

Keywords: privacy, perception, nursing, midwifery

Percepciones de los estudiantes de obstetricia y enfermería sobre la intimidad corporal y la autoestima. El caso de Turquía

Resumen: El artículo informa de los resultados de un estudio llevado a cabo para examinar las percepciones de la intimidad corporal de los estudiantes de obstetricia y enfermería y los factores que afectan a sus percepciones. Se trató de un estudio transversal, con 389 estudiantes de obstetricia y enfermería de una universidad pública que se ofrecieron a participar en el estudio. Los datos se recogieron mediante un "Formulario de información personal", la "Escala de confidencialidad corporal para ginecología y obstetricia" y la "Escala de autoestima de Rosenberg". Los participantes tenían una edad media de 20,89 1,86 ańos. La puntuación media que dieron a la cuestión de si prestaban atención a la intimidad fue de $8,21 \pm 1,88$. La puntuación media de la autoestima de Rosenberg fue de 29,44 \pm 4,83 (mínimo = 10, máximo $=40$ ). La puntuación media de privacidad general fue de 36,10 $\pm 6,84$ ( $\operatorname{mín}=9$, máx $=45)$, la de derechos y privacidad fue de 20,80 $\pm 3,71$ ( mín = 5, máx $=25)$, la de ética y privacidad fue de 20,45 \pm 3,67 (mín = 5, máx = 25), y la de privacidad clínica fue de 75,22 $\pm 12,33$ (mín = 18, máx = 90). De acuerdo con los resultados, los estudiantes de obstetricia y enfermería, que intervendrían luego en la salud de las mujeres, tenían una autoestima y una percepción de la privacidad superiores a la media. No obstante, el establecimiento del concepto de "privacidad" es una cuestión que debería abordarse y reforzarse en la formación de los estudiantes de obstetricia y enfermería que van a prestar servicios en un ámbito tan delicado como la ginecología y la obstetricia.

Palabras clave: privacidad, percepción, enfermería, obstetricia

Percepçóes dos estudantes de obstetrícia e de enfermagem sobre a intimidade corporal e a autoestima. $\mathrm{O}$ caso da Turquia

Resumo: $\mathrm{O}$ artigo informa sobre os resultados de um estudo realizado para examinar as percepçóes da intimidade corporal dos estudantes de obstetrícia e de enfermagem e os fatores que afetam suas percepçóes. Trata-se de um estudo transversal, com 389 estudantes de obstetrícia e de enfermagem de uma universidade pública que se ofereceram para participar no estudo. Os dados foram coletados mediante um "Formulário de informaçáo pessoal", a "Escala de confidencialidade corporal para ginecologia e obstetrícia" e a "Escala de autoestima de Rosenberg". Os participantes tinham uma idade média de 20,89 $\pm 1,86$ anos. A pontuaçáo média que deram à questáo de se prestavam atençáo à intimidade foi de $8,21 \pm 1,88$. A pontuaçáo média de autoestima de Rosenberg foi de 29,44 \pm 4,83 (mínimo = 10, máximo = 40). A pontuação média de privacidade geral foi de 36,10 $\pm 6,84$ $(\min =9, \max =45)$, a de direitos e privacidade foi de 20,80 $\pm 3,71(\min =5, \max =25)$, a de ética e privacidade foi de 20,45 \pm $3,67(\min =5, \max =25)$ e a de privacidade clínica foi de 75,22 $\pm 12,33(\min =18, \max =90)$. De acordo com os resultados, os estudantes de obstetrícia e de enfermagem, que logo iriam intervir na saúde das mulheres, tinham uma autoestima e uma percepção da privacidade superiores à média. Não obstante, o estabelecimento do conceito de "privacidade" é uma questão que deveria ser abordada e reforçada na formaçáo dos estudantes de obstetrícia e de enfermagem que irão prestar serviços em um âmbito tão delicado como a ginecologia e a obstetrícia.

Palavras chave: privacidade, percepção, enfermagem, obstetrícia

\footnotetext{
${ }^{1}$ Ufuk University School of Medicine, Ankara, Türkiye. ORCID: 0000-0003-4851-5786

Correspondence: gunmukadder@yahoo.co.uk

${ }^{2}$ Balıkesir University Faculty of Health Sciences, Balıkesir, Türkiye. ORCID: 0000-0002-0402-6959

Correspondence: aslantekinfiliz@yahoo.com
} 


\section{Introduction}

Privacy, one of the fundamental concepts of human rights, is defined as knowledge, data or a circumstance in which a person must give permission to uncover and reveal any matter that belongs to the person(1). The Turkish Language Association's Dictionary of Nursing Terms defines privacy as "data/information belonging to a person that should not be disclosed, or that requires the consent of the person or a guardian to be shared, something personal, or confidentiality" (2). Siegler has addressed privacy in the field of health and medicine as a concept that serves to improve respect for people's personality and confidentiality and to improve patients' health care, which is one of the main objectives of medicine. As a consequence of respect for personality and confidentiality, patients' most personal physical and psychological secrets are kept secret in order to reduce their embarrassment and sensitivity(3).

Privacy is most often discussed with concepts such as confidentiality, private life, information, religion, private space, sexuality and culture. The concept of privacy is perceived in different ways depending on cultural characteristics of societies. However, there are rules on privacy and private life immunity in every culture(4). The sense of trust created by ensuring privacy is treated as a fundamental value in all human relationships. People easily go to healthcare institutions and organizations to seek the services they need only if the bond of trust is safeguarded(5). For these reasons, privacy is an issue in health services to which attention should be paid. Special attention should be given to privacy when women seek advice on issues in women's health services such as sexual problems, drug use for urinary infection, rectal or intravaginal drug administration(6). Research shows that if one is not sensitive to privacy during gynecological and obstetric examination, it creates an extreme sense of shame and fear in women(7-10). Attention should be paid to a woman's privacy while she is being examined as she would be uncomfortable that the most intimate parts of her body would be seen and touched by people she sees for the first time. The act of childbirth, in particular, is an event where privacy is the most important issue. The environmental impact of labor and labor pain in laboratory mice has been studied, and mice suffering from labor pain have been shown to feel fear and stress in an environment where their privacy has not been guaranteed(11). The increase in the level of catecholamine in an environment where privacy is not guaranteed causes it to stop labor pain in the early period(12). During labor, women struggle to cope with being in an environment they are not familiar with, protecting their privacy, and going through the childbirth process. In this process, the mother needs psychological support and trust. Privacy is important in that it meets the social needs of people in health care. A privacy-sensitive approach encourages patients to communicate honestly and properly while assuring the patient that the information they provide will not be disclosed to others(6). It is an indispensable element for midwives/nurses, who offer primary care, to give mother and baby sensitive care, in order to increase their health and healthcare quality in the process of childbirth, which has tremendous value and meaning for every woman(13).

A respectful approach to privacy is a prerequisite for the principle of respect for people. To value human beings, each person has to respect himself or herself, they have to have self-acceptance, with a healthy sense of selfhood. According to the professional values of midwifery and nursing, informed consent, respect for privacy, respect for differences, and respect for women's values and themselves are imperative ethical responsibilities. It is important for health professionals to have high self-esteem. Midwives' and nurses' communications skills and self-esteem are two factors which affect one another and improve the capacity for their professional success(14). High self-esteem positively influences the care midwives/nurses provide for patients, whereas low self-esteem adversely influences the level and quality of care they provide to patients. Offering effective midwifery/ nursing care necessitates high self-esteem $(15,16)$. Students are supposed to boost their self-esteem throughout midwifery/nursing education, as this educational process is professionally part of the process of self-esteem development. Students' personal and professional development, self-confidence and self-esteem influence their communication with patients. Personal development, and improved confidence and self-esteem are positive 
outcomes of student experiences. In this context, students who will become healthcare professionals of the future should learn being responsible in order to ensure patient trust, to defend their interests and well-being, to maintain the principle of defending them, communicating with them, being honest and accurate to them, to respect their religious faith, to provide care by protecting their values, to act in accordance with ethical principles and to respect privacy, and so forth. These are critical elements in patient care(17). Ethically healthcare professionals are obliged to protect patient privacy $(18,19)$. Especially the complexities of gynecology and obstetrics harbor factors that may make upholding ethical obligations more difficult and challenging. Ensuring patient privacy is reflective of patient participation in treatment and care, healthcare professionals upholding their legal and professional obligations, and effective communication between the patient and healthcare professionals. For this reason, it is important to examine how professionals in the healthcare sector view privacy and how they approach to the concept of privacy.

\section{Method}

The population of the study consisted of the students of the Departments of Midwifery and Nursing at Balıkesir University Faculty of Health Sciences, and the sample consisted of 389 students who agreed to participate in the study. Permissions for the study were obtained. Data of the study were collected using the survey method through the self-reporting technique. A personal information form containing personal data was administered to determine the sociodemographic statuses off the participants. The Body Confidentiality Scale for Gynecology and Obstetrics developed by Değirmen was administered to determine the privacy statuses of the students. And, the "Rosenberg Self-Esteem Scale (RSES)" developed by Rosenberg (1963) and adapted to Turkish by Çuhadaroğlu (1986) was administered to evaluate self-esteem.

\section{Personal Information Form}

A survey form consisting of questions inquiring participants' personal information was prepared by the researchers.

\section{Body Confidentiality Scale for Gynecology and Obstetrics}

The Body Confidentiality Scale for Gynecology and Obstetrics (BCSGO) was developed by Nuriye Değirmen in 2014 specifically for our country. Based on the reliability analysis, the Crohnbach's Alpha value for the overall dimensions of the scale was 0.840. The Body Confidentiality Scale for Gynecology and Obstetrics consists of 37 (thirtyseven) questions and 4 sub-dimensions as general privacy, rights and privacy, ethics and privacy, and clinical privacy.

The scale does not have any total score or a cut-off score. The sum of the items that make up each sub-dimension is used as "a total sub-dimensional score." It is considered that the perception of privacy is more important as the sum of sub-dimension scores on the scale increase(20).

\section{Rosenberg Self-Esteem Scale}

It is a measurement instrument developed by Rosenberg (1963). It was tested for validity and reliability in Turkish by Çuhadaroğlu (1986). It has 10 items that evaluate people's self-esteem through 4-point Likert-type options: $(1=$ "Strongly agree," 2 = "Agree," 3 = "Disagree," 4 = "Strongly disagree"). Items 1, 2, 4, 6, and 7 of the scale are normally coded; items 3, 5, 8, 9, and 10 are reverse coded (calculated by inverting). When scoring the scale, low scores point to high selfesteem and high scores point to low self-esteem.

\section{Results}

A total of 389 students participated in the study. The participants were $20.89 \pm 1.86$ years old on average; $58.9 \%$ were studying at the department of midwifery, and $41.1 \%$ at the department of nursing; $11.6 \%$ were freshmen, $30.1 \%$ were sophomores, $28.3 \%$ were juniors, and $30 \%$ were seniors. It was stated by $70.2 \%$ of the students that they chose the department willingly, and by $29.8 \%$ unwillingly. When asked about the reasons why they chose their departments, $53.5 \%$ indicated that they chose the department because their families wanted it, $18.5 \%$ because they liked the profession, and $15.7 \%$ because the graduates of the department had plenty of opportuni- 
ties to find a job. Of the students, $58.6 \%$ were satisfied with the department they were studying in; $70.7 \%$ took courses on ethics but $29.3 \%$ did not. The students gave the question "How do you rate whether attention is paid to privacy in clinical applications?" an average score of $6.53 \pm 2.14$ in their assessment out of 10 points. The average score they gave to whether they themselves paid attention to privacy was $8.21 \pm 1.88$. The mean Rosenberg self-esteem score was $29.44 \pm 4.83$ ( $\mathrm{min}$ $=10, \max =40)$. Mean general privacy score was $36.10 \pm 6.84(\min =9, \max =45)$, rights and privacy score was $20.80 \pm 3.71(\min =5, \max =25)$, ethics and privacy score was $20.45 \pm 3.67$ ( $\mathrm{min}=$ 5 , $\max =25)$, and clinical privacy score was 75.22 $\pm 12.33(\min =18, \max =90)($ Table 1$)$.

The students' total scores on general privacy, rights and privacy, ethics and privacy, clinical privacy, and self-esteem scales did not differ significantly depending on the following variables: maternal and paternal educational statuses, place of residence for a long time, voluntarily selecting the department, and taking a course on ethics ( $\mathrm{p}$ > $0.05)$.

The students' rights and privacy $(\mathrm{t}=-2.8, \mathrm{p}=$ $0.00)$, ethics and privacy $(t=-2.9, p=0.00)$, clinical privacy $(\mathrm{t}=-2.2, \mathrm{p}=0.02)$, self-esteem $(\mathrm{t}=$ $-2.3, p=0.02)$ total scores on the scales showed a significant difference according to gender. The scores of the female students were higher.

There were significant differences in ethics and privacy $(\mathrm{t}=-1.9, \mathrm{p}=0.04)$, clinical privacy $(\mathrm{t}=$ $-2.2, \mathrm{p}=0.02)$, and self-esteem $(\mathrm{t}=-2.2, \mathrm{p}=0.00)$ when compared according to the department where they studied. The scores in the department of midwifery were higher.

The scores on the clinical privacy sub-dimension of the privacy scale $(\mathrm{f}=-4.4 \mathrm{p}=0.00)$ and selfesteem scale $(t=2.7 p=0.02)$ differed depending on the grade levels of the students. The mean scores were higher among the freshmen students than among the students in other grade levels.

The rights and privacy sub-dimension scores of the scale differed significantly depending on the income level of the students $(f=2.9, p=0.05)$. Those who had more income than their expenses were found to score low on the rights and privacy sub-dimension.

Clinical privacy $(\mathrm{t}=2.0, \mathrm{p}=0.03)$ and self-esteem $(t=3.3, p=0.00)$ scale scores were found to differ depending on satisfaction with the department. The students who were satisfied with their department had higher mean scores (Table 2).

When the relationship between the students' scores on the self-esteem scale and the sub-dimensions of body privacy in obstetrics was tested by using Pearson correlation analysis, positive correlations were found in all sub-dimensions. It was found that as self-esteem increased, scores on general rights and privacy $(\mathrm{p}=0.02)$, rights and privacy $(\mathrm{p}$ $=0.00)$, ethics and privacy $(\mathrm{p}=0.01)$, and clinical privacy $(p=0.00)$ increased, and self-esteem was found to correlate with them significantly (Table 3).

Multiple linear regression analysis was carried out to investigate the independent variables affecting the rights and privacy sub-dimension in the study (Table 3). Based on the analysis, it was found that there was a significant relationship between the rights and privacy sub-dimension and self-esteem and gender that explained $7 \%\left(\mathrm{R}^{2}=0.078\right)$ of the variance (Table 4).

Multiple linear regression analysis was carried out to investigate the independent variables affecting the ethics and privacy sub-dimension in the study (Table 4). Based on the analysis, it was found that there was a significant relationship between the ethics and privacy sub-dimension and self-esteem and gender that explained $0.4 \%\left(R^{2}=0.043\right)$ of the variance (Table 5).

Multiple linear regression analysis was carried out to investigate the independent variables affecting the clinical privacy sub-dimension in the study (Table 5). Based on the analysis, it was found that there was a significant relationship between the clinical privacy sub-dimension and self-esteem and gender that explained $0.4 \%\left(R^{2}=0.041\right)$ of the variance.

\section{Discussion}

The mean general privacy score of the nursing and 
midwifery students participating in the study was 36.10 , the rights and privacy score was 20.80 , the ethical and privacy score was 20.45 , and the clinical privacy score was 75.22 on the Body Confidentiality Scale for Gynecology and Obstetrics. The perception of privacy was found to be well above the mid value of the scale, as in the study of Değirmen(20). A related research on midwifery students showed that the mean privacy score was strong and that students paid attention to protecting and maintaining the privacy of patients(21). The mean score on the privacy awareness scale was $46.59 \pm 8.19(\min =18, \max =55)$ in a study conducted by Tosun et al.(22). In a study carried out nursing students and nursing instructors expressed that they believed that "Protect the privacy of the patient" and "Protect the moral and legal rights of patients" were the most important items(23). It has been stated also in other research studies that nurses and nursing students attach great importance to concepts such as respect, privacy, confidentiality, support and high quality nursing care(24-26).

In our study, the students' scores on rights and privacy, ethics and privacy, and clinical privacy scales were found to differ significantly depending on gender. Scores of the female students were found to be higher. Similarly, in another study conducted by Değirmen using the Body Confidentiality Scale for Gynecology and Obstetrics, scores of doctors, midwives and nurses on clinical privacy sub-dimensions were found to differ statistically significantly in terms of gender women had higher scores(20).

According to the findings of the present study, there were no significant differences in the students' total scores on the general privacy, rights and privacy, ethics and privacy, and clinical privacy sub-dimensions depending on their maternal and paternal educational statuses, place of residence for a long time, choosing the department willingly, and taking a course on ethics. Tosun et al., have also noted that privacy scores do not differ depending on taking courses on ethics or ethical principles(22).

The students' mean scores on ethics and privacy and clinical privacy varied significantly depending on the department where the students were stud- ying. The scores of the students of the department of midwifery were higher. This difference indicates that students studying at the department of midwifery may be more responsive due to the fact that they provide gynecological and obstetric care in midwifery practices.

With regard to grade levels of the students, mean scores on the clinical privacy sub-dimension of the privacy scale were found to be higher in freshmen students compared to others. Bahadır-Yilmaz and Ekin have reported that senior students have a more positive attitude towards patient privacy than other university students(21). Tosun et al. found that when they examined midwifery students for sensitivity to privacy based on grade levels, they found that there was a difference between the levels(22). As we identified in the results of our study, they found that freshmen students were more conscious of privacy than junior students. According to the findings of our study, the fact that the freshmen students were more sensitive may be due to the sensitivity that occurs due to the focus of ethical principles and patient privacy within the scope of the Introduction to Midwifery Course.

The mean score on the Rosenberg Self-Esteem Scale (RSES) was 29.44 \pm 4.83 and was above the mid-point of the scale. Aktaş et al. conducted a study on nursing students and stated that the total RSES score was 29.51 and was moderately high(27). The findings of the present study show that the students' self-esteem was also above the average and was similar to the academic literature.

There was a positive relationship between the students' satisfaction with the department and their scores on the clinical privacy scale. Those who were satisfied with their department had higher mean scores. Accordingly, those who were satisfied with the department where they were studying paid more attention to clinical privacy. Tosun et al. have stated that there is no relationship between privacy awareness and whether a person loves his career(22).

In this study, self-esteem varied significantly depending on gender $(\mathrm{p}=0.02)$, department of study $(p=0.02)$, grade level $(p=0.02)$, and satisfaction with the department $(\mathrm{p}=0.00)$. High self- 
esteem implies that the satisfaction of the students with their departments was greatly influenced by their willingly choosing their departments.

In the present study, the self-esteem scores were significantly higher in female students compared with those in male students. There are studies in academic literature reporting that self-esteem scores are higher in female students than in male students, as well as studies reporting that there is no association between self-esteem and gen$\operatorname{der}(27-30)$.

The students of the department of midwifery were found to have stronger self-esteem in this study. It is mentioned in Dinçer's study that self-perception was found to be stronger among midwifery students than among nursing students. Self-esteem was high among midwifery students also in the study of Özkan and Bayat, but it was not found significant. In the study of Ünsar and İssever, the level of self-esteem of nursing department students was high but was not significantly diffe$\operatorname{rent}(31-33)$.

In the present study, self-perception among the freshmen students was found to be high but found to decrease as the years of study increased. In addition to studies in which there is no relationship between grade level and self-esteem, there are studies in academic literature which indicate that self-esteem increases as grade level rises. There are also studies which claim the opposite, that self-esteem declines as grade level rises. It is shown that a number of studies have linked the decrease in self-esteem due to advancing grade level with the perception that midwifery/nursing education is a stressful experience $(28,29,31,34)$.

RSES scores were found to correlated positively with the general rights and privacy, ethics and privacy, and clinical privacy scores, which were the sub-dimensions of BCSGO. As RSES increases, so does the perception of privacy. Self-esteem and gender were found to be effective in each of the individual regression models for the rights and privacy, ethics and privacy and clinical privacy sub-dimensions, which were the sub-dimensions of BCSGO. Privacy is a measure of how close people can get to each other, both physically and cognitively, while communicating and in rela- tions. Therefore, privacy is a significant finding in the context of maintaining self-esteem and giving a person the right to limit social relationships. Strong privacy awareness among people with high self-esteem can be considered a positive situation. This requires acknowledgment of a gender-sensitive strategy in delivering healthcare, rather than relying exclusively on biological gender. In this context, it will be more appropriate to approach the topic of privacy in a respectful way while teaching male nursing students, and to make an attempt to improve their awareness.

\section{Conclusion and Recommendations}

According to the results, the most important factors affecting the perception of privacy of the students were the level of self-esteem and gender in this study, which was undertaken to explore midwifery and nursing students' perceptions of body privacy in terms of gynecology and obstetrics and the factors affecting their perceptions. In this respect, ensuring that the concept of privacy is adapted appropriately and providing healthcare practices with an educational philosophy focused on attention paid to privacy and adherence to the principle of people's autonomy will make substantial contributions by building trust between healthcare professionals and service clients. The factors that influence this perception must be taken into account in a holistic manner in order for healthcare professionals to develop a perception of privacy. In training programs to improve student self-esteem, it is important to have strategies and methods in which gender is emphasized. Self-esteem development is a turning point in adolescence, and the process of midwifery/nursing education is also an important time frame. For this reason, students should be given opportunities to develop self-esteem and perceptions of privacy during this period. Quantitative and qualitative research should be carried out to identify midwifery/nursing students' awareness of self-esteem and privacy awareness and to determine the problems they experience in clinical practices. It is thought that promoting midwifery and nursing education is advantageous with instructional approaches such as content analysis and case analysis that are ideal for the growth of self-esteem and privacy awareness. 
Table 1: Comparison of BCSGO Sub-Dimension Scores and RSES Scores by Sociodemographic Characteristics

\begin{tabular}{|c|c|c|c|c|c|c|}
\hline $\begin{array}{l}\text { Demographic } \\
\text { Characteristics }\end{array}$ & $\mathbf{N}$ & General privacy & $\begin{array}{l}\text { Rights and } \\
\text { privacy }\end{array}$ & $\begin{array}{l}\text { Ethics and } \\
\text { privacy }\end{array}$ & $\begin{array}{l}\text { Clinical } \\
\text { privacy }\end{array}$ & \begin{tabular}{|l|} 
Self- \\
esteem
\end{tabular} \\
\hline Gender & & Mean \pm SD & Mean \pm SD & Mean \pm SD & Mean \pm SD & $\begin{array}{l}\text { Mean } \pm \\
\text { SD }\end{array}$ \\
\hline Male & & $34.9 \pm 8.8$ & $19.4 \pm 4.4$ & $19.0 \pm 4.4$ & $71.4 \pm 15.1$ & $28.0 \pm 5.3$ \\
\hline Female & & $36.3 \pm 6.3$ & $21.0 \pm 3.4$ & $20.7 \pm 3.4$ & $76.0 \pm 11.5$ & $29.7 \pm 4.6$ \\
\hline $\mathrm{T}$ & & -1.2 & -2.8 & -2.9 & -2.2 & -2.3 \\
\hline $\mathrm{P}$ & & 0.2 & 0.00 & 0.00 & 0.02 & 0.02 \\
\hline Department & & Mean \pm SD & Mean \pm SD & Mean \pm SD & Mean \pm SD & $\begin{array}{l}\text { Mean } \pm \\
\text { SD }\end{array}$ \\
\hline Midwifery & & $36.6 \pm 6.4$ & $21.1 \pm 3.5$ & $20.9 \pm 3.4$ & $76.8 \pm 11.3$ & $30.0 \pm 4.2$ \\
\hline Nursing & & $35.6 \pm 7.1$ & $20.5 \pm 3.8$ & $20.1 \pm 3.8$ & $74.1 \pm 12.9$ & $29.0 \pm 5.1$ \\
\hline $\mathrm{T}$ & & -1.4 & -1.5 & -1.9 & -2.2 & -2.2 \\
\hline $\mathrm{P}$ & & 0.16 & 0.12 & 0.04 & 0.02 & 0.02 \\
\hline Grade Level (year of study) & & Mean \pm SD & Mean \pm SD & Mean \pm SD & Mean \pm SD & $\begin{array}{l}\text { Mean } \pm \\
\text { SD }\end{array}$ \\
\hline 1 & & $38.4 \pm 9.6$ & $21.4 \pm 4.2$ & $21.1 \pm 3.5$ & $80.0 \pm 11.0$ & $30.6 \pm 4.3$ \\
\hline 2 & & $35.8 \pm 6.2$ & $21.0 \pm 3.4$ & $20.2 \pm 3.7$ & $74.7 \pm 12.4$ & $30.1 \pm 4.9$ \\
\hline 3 & & $36.6 \pm 7.4$ & $21.0 \pm 3.5$ & $20.7 \pm 3.4$ & $77.1 \pm 11.6$ & $29.2 \pm 5.1$ \\
\hline 4 & & $35.0 \pm 6.4$ & $20.1 \pm 3.8$ & $20.1 \pm 3.8$ & $72.2 \pm 12.4$ & $28.4 \pm 4.4$ \\
\hline$f$ & & 2.3 & 1.5 & 0.9 & 4.4 & 2.7 \\
\hline $\mathrm{P}$ & & 0.06 & 0.18 & 0.45 & 0.00 & 0.02 \\
\hline Maternal Educational Level & & Mean \pm SD & Mean \pm SD & Mean \pm SD & Mean \pm SD & $\begin{array}{l}\text { Mean } \pm \\
\text { SD }\end{array}$ \\
\hline $\begin{array}{l}\text { Elementary School Graduate } \\
\text { or Lower }\end{array}$ & & $35.8 \pm 6.5$ & $20.7 \pm 3.7$ & $20.5 \pm 3.6$ & $74.9 \pm 12.0$ & $29.5 \pm 4.8$ \\
\hline $\begin{array}{l}\text { Secondary School or College } \\
\text { Graduate }\end{array}$ & & $36.7 \pm 7.3$ & $20.9 \pm 7.3$ & $20.3 \pm 3.7$ & $75.8 \pm 12.9$ & $29.2 \pm 4.7$ \\
\hline $\mathrm{T}$ & & -1.1 & -0.6 & 0.4 & -0.6 & 0.4 \\
\hline $\mathrm{P}$ & & 0.24 & 0.51 & 0.62 & 0.52 & 0.62 \\
\hline Paternal Educational Level & & Mean \pm SD & Mean \pm SD & Mean \pm SD & Mean \pm SD & $\begin{array}{l}\text { Mean } \pm \\
\text { SD }\end{array}$ \\
\hline $\begin{array}{l}\text { Elementary School Graduate } \\
\text { or Lower }\end{array}$ & & $35.8 \pm 7.4$ & $20.5 \pm 3.9$ & $20.2 \pm 3.8$ & $74.7 \pm 12.9$ & $29.4 \pm 4.7$ \\
\hline $\begin{array}{l}\text { Secondary School or College } \\
\text { Graduate }\end{array}$ & & $36.4 \pm 6.0$ & $21.0 \pm 3.4$ & $20.6 \pm 3.4$ & $15.8 \pm 11.6$ & $29.3 \pm 4.9$ \\
\hline $\mathrm{T}$ & & -0.9 & -1.4 & -0.9 & -0.8 & 0.2 \\
\hline $\mathrm{P}$ & & 0.34 & 0.14 & 0.35 & 0.39 & 0.81 \\
\hline $\begin{array}{l}\text { Perceived Monthly Income } \\
\text { Level }\end{array}$ & & Mean \pm SD & Mean \pm SD & Mean \pm SD & Mean \pm SD & $\begin{array}{l}\text { Mean } \pm \\
\text { SD }\end{array}$ \\
\hline Income is less than expenses & & $36.5 \pm 5.5$ & $20.9 \pm 3.1$ & $20.8 \pm 3.2$ & $76.2 \pm 10.4$ & $29.4 \pm 4.6$ \\
\hline Income is equal to expenses & & $36.1 \pm 7.2$ & $20.9 \pm 3.8$ & $20.3 \pm 3.7$ & $75.2 \pm 12.7$ & $29.3 \pm 4.9$ \\
\hline $\begin{array}{l}\text { Income is greater than } \\
\text { expenses }\end{array}$ & & $35.0 \pm 5.8$ & $19.2 \pm 3.6$ & $19.9 \pm 3.5$ & $75.5 \pm 12.8$ & $30.2 \pm 4.4$ \\
\hline$f$ & & 0.5 & 2.9 & 0.8 & 0.9 & 0.4 \\
\hline $\mathrm{p}$ & & 0.57 & 0.05 & 0.43 & 0.37 & 0.66 \\
\hline $\begin{array}{l}\text { Place of Residence for A } \\
\text { Long Time }\end{array}$ & & Mean \pm SD & Mean \pm SD & Mean \pm SD & Mean \pm SD & $\begin{array}{l}\text { Mean } \pm \\
\text { SD }\end{array}$ \\
\hline $\begin{array}{l}\text { Village/Town/District } \\
\text { Center }\end{array}$ & & $35.7 \pm 7.2$ & $20.5 \pm 3.7$ & $20.2 \pm 3.7$ & $75.0 \pm 12.3$ & $29.2 \pm 4.7$ \\
\hline
\end{tabular}


Midwife and nurse students' perceptions of body privacy and Self Esteem - Gün Mukadder, Aslantekin Özçoban Filiz

\begin{tabular}{|c|c|c|c|c|c|}
\hline $\begin{array}{l}\text { Provincial Center/ } \\
\text { Metropolitan }\end{array}$ & $36.7 \pm 6.1$ & $21.2 \pm 3.6$ & $20.7 \pm 3.5$ & $75.5 \pm 12.2$ & $26.6 \pm 4.9$ \\
\hline $\mathrm{t}$ & -1.4 & -1.8 & -1.2 & -0.4 & -0.7 \\
\hline $\mathrm{p}$ & 0.14 & 0.06 & 0.21 & 0.66 & 0.47 \\
\hline $\begin{array}{l}\text { Did you prefer the } \\
\text { department willingly? }\end{array}$ & Mean \pm SD & Mean \pm SD & Mean \pm SD & Mean \pm SD & $\begin{array}{l}\text { Mean } \pm \\
\text { SD }\end{array}$ \\
\hline Yes & $36.4 \pm 6.7$ & $20.9 \pm 3.6$ & $20.5 \pm 3.6$ & $75.9 \pm 11.9$ & $29.6 \pm 4.9$ \\
\hline No & $35.4 \pm 6.9$ & $20.5 \pm 3.9$ & $20.1 \pm 3.7$ & $73.6 \pm 13.1$ & $28.8 \pm 4.5$ \\
\hline $\mathrm{t}$ & 1.3 & 0.8 & 0.9 & 1.6 & 1.4 \\
\hline $\mathrm{p}$ & 0.18 & 0.39 & 0.31 & 0.10 & 0.15 \\
\hline $\begin{array}{l}\text { Are you satisfied with the } \\
\text { department? }\end{array}$ & Mean \pm SD & Mean \pm SD & Mean \pm SD & Mean \pm SD & $\begin{array}{l}\text { Mean } \pm \\
\text { SD }\end{array}$ \\
\hline Yes & $36.4 \pm 6.3$ & $21.0 \pm 3.6$ & $20.7 \pm 3.5$ & $76.6 \pm 11.4$ & $30.1 \pm 5.1$ \\
\hline No & $36.0 \pm 7.2$ & $20.6 \pm 3.8$ & $20.2 \pm 3.7$ & $73.6 \pm 13.0$ & $28.4 \pm 4.2$ \\
\hline $\mathrm{t}$ & 0.5 & 0.8 & 1.0 & 2.0 & 3.3 \\
\hline $\mathrm{p}$ & 0.59 & 0.37 & 0.28 & 0.03 & 0.00 \\
\hline $\begin{array}{l}\text { Have you ever taken any } \\
\text { course on ethics? }\end{array}$ & Mean \pm SD & Mean \pm SD & Mean \pm SD & Mean \pm SD & $\begin{array}{l}\text { Mean } \pm \\
\text { SD }\end{array}$ \\
\hline Yes & $36.4 \pm 6.7$ & $20.8 \pm 3.7$ & $20.5 \pm 3.6$ & $75.4 \pm 12.0$ & $29.6 \pm 4.9$ \\
\hline No & $35.3 \pm 6.8$ & $20.7 \pm 3.6$ & $20.3 \pm 3.7$ & $74.9 \pm 13.1$ & $29.0 \pm 4.4$ \\
\hline $\mathrm{t}$ & 1.3 & 0.1 & 0.5 & 0.3 & 1.1 \\
\hline $\mathrm{p}$ & 0.16 & 0.85 & 0.56 & 0.74 & 0.25 \\
\hline
\end{tabular}

Table 2: Relationship Between Midwifery and Nursing Students' BCSGO Sub-Dimension Scores and RSES Scores

\begin{tabular}{|l|l|l|l|l|}
\hline Self-esteem scale & General privacy & Rights and privacy & Ethics and privacy & Clinical privacy \\
\hline $\mathbf{r}$ & 117 & .226 & .161 & .229 \\
\hline $\mathbf{p}$ & $0.02^{*}$ & $0.00^{* *}$ & $0.01^{* *}$ & $0.00^{* *}$ \\
\hline
\end{tabular}

Table 3: Multiple Linear Regression Analysis of Independent Variables Affecting Rights and Privacy Sub-Dimensions

\begin{tabular}{|l|l|l|l|l|l|}
\hline & $\mathbf{B}$ & $\mathbf{t}$ & $\mathbf{p}$ & \multicolumn{2}{l|}{ 95\% confidence interval } \\
\hline Self-esteem & 0.161 & 4.247 & .000 & 0.087 & 0.236 \\
\hline Gender & 1.368 & 0.486 & 0.05 & 0.087 & 0.236 \\
\hline Monthly income & -0.600 & 0.351 & 0.088 & -1.290 & 0.090 \\
\hline
\end{tabular}

$\mathrm{R}=0.279, \mathrm{R}^{2}=0.78$, Durbin-Watson $=1.867(\mathrm{p}<0.0000)$ 
Table 4: Multiple Linear Regression Analysis of Independent Variables Affecting Ethics and Privacy Sub-Dimension

\begin{tabular}{|l|l|l|l|l|l|}
\hline & B & t & p & \multicolumn{2}{|l|}{ 95\% confidence interval } \\
\hline Self-esteem & 0.140 & 2.776 & 0.00 & 0.031 & 0.11 \\
\hline Gender & 0.149 & 2.76 & 0.00 & 0.414 & 2.466 \\
\hline Department & 0.019 & .354 & .723 & -0.618 & 0.889 \\
\hline
\end{tabular}

$\mathrm{R}=0.224, \mathrm{R}^{2}=0.043$, Durbin-Watson $=1.881(\mathrm{p}<0.0000)$

Table 5: Multiple Linear Regression Analysis of Independent Variables Affecting Clinical Privacy SubDimension

\begin{tabular}{|l|l|l|l|l|l|}
\hline & B & t & p & 95\% confidence interval \\
\hline Self-esteem & 0.128 & 2.484 & 0.01 & .020 & .174 \\
\hline Gender & .150 & 2.788 & 0.00 & .429 & 2.485 \\
\hline Department & .007 & 0.128 & 0.89 & -.723 & .823 \\
\hline Grade with & -.020 & -.380 & 0.70 & -.437 & .296 \\
\hline $\begin{array}{l}\text { Satisfaction } \\
\text { the department }\end{array}$ & -.054 & -1.064 & 0.28 & -.912 & .272 \\
\hline
\end{tabular}

$\mathrm{R}=0.231, \mathrm{R}^{2}=0.041$, Durbin-Watson $=1.876(\mathrm{p}<0.0000)$ 
Midwife and nurse students' perceptions of body privacy and Self Esteem - Gün Mukadder, Aslantekin Özçoban Filiz

\section{References}

1. Arslan ET, Demir H. Sağlık çalışanlarının Hasta Mahremiyetine İlişkin Tutumu;Nitel bir araştırma. AİBÜ Sosyal Bilimler Enstitüsü Dergisi 2017, 17(4); 191-220.

2. TDK, Hemşirelik Terimleri Sözlüğü. Available from: httpp://www.tdk.gov.tr./ddk/ddk62pdf. Erişim Tarihi:20.02.2020.

3. Sieglar M. Confidentally in Medicine. A Decrepit Concept. N England Journal of Medicine 1982; 307(24): 1518-1521.

4. Akyüz EB. Ameliyat Olan Hastalarda Hemşirelik Bakım Uygulamalarının Mahremiyetel Kişisel Gizliliğe Etkileri Konusunda Hastalarnn ve Hemşirelerin Görüşleri. B.Ü. Sağl1k Bilimleri Enstitüsü, Yüksek Lisans Tezi; 2008.

5. İzgi C. Mahremiyet Kavramı Bağlamında Kişisel Sağlık Verileri. Türkiye Biyoetik Dergisi 2014; 1(1): 25-37.

6. Mobach MP. Counter design influences the privacy of patients in healthcare. Soc Sci Medicine 2009; 68: 1000-1005.

7. Erbil N, Senkul A, Sağlam Y, Ergul, N. Determination of attitudes with gynaecologic examination and anxiety of Turkish women before gynaecologic examination. International Journal of Human Sciences 2008; 5(1), 1-13.

8. Yanikkerem E, Özdemir M, Bingol H, Tatar A, Karadeniz G. Women's attitudes and expectations regarding gynaecological examination. Midwifery 2009; 25(5): 500-508.

9. Downe S, Gyte GM, Dahlen HG, Singata M. Routine vaginal examinations for assessing progress of labour to improve outcomes for women and babies at term. The Cochrane Collaboration 2013; 15(7): 1-42.

10. Hassan S, Sundby J, Husseini A, Bjertness E. Palestinian women's feelings and opinions about vaginal examinations during normal childbirth: an exploratory study. The Lancet Journal 2012; 380: 35.

11. Newton N, Foshee D, Newton M. Experimental inhibition of labor through environmental disturbance. Obstetrics \& Gynecology 1966; 27(3): 371-377.

12. Lothian JA. Do not disturb: the importance of privacy in labor. The Journal of Perinatal Education 2004; 13: 4-6.

13. Üzeltürk S. [1982 Constitution and Human Rights, the right to privacy under the European Convention] 1982 Anayasası ve İnsan Hakları Avrupa Sözleşmesine göre özel hayatın gizliliği hakkı. İstanbul: Beta Yayıncılık; 2004: 99-109.

14. Lo R.A. Longitudinal study of perceived level of stress, coping and self-esteem of under graduate nursing students: An Australian case study. Journal of Advanced Nursing (Electronic Journal) 2002; 39(2): 119-126.

15. Randle J. The effect of a 3-year pre-registration training course on student's self esteem. Journal of Clinical Nursing (Electronic Journal) 2001; 10(2): 293-300.

16. Randle J. Changes in self-esteemduring a 3-year pre-registration diploma in higher education (nursing) programme. Journal of Clinical Nursing (Electronic Journal) 2003; 12(1): 142-143.

17. Calleja P, Forrest L. Improving patient privacy and confidentiality in on eregional emergency department —a quality project. Australasian Emerg Nurs J. 2011; 14: 251-256. DOI: 10.1016/j.aenj.2011.05.002.

18. Moskop JC, Marco CA, Larkin GL, Geiderman JM, Derse AR. From Hippocratesto HIPAA: privacy and confidentiality in emergency medicine part I: conceptual, moral, and legal foundations. Ann Emerg Med 2005; 45 (1): 53-59. DOI: 10.1016/j.annemergmed.2004.08.008.

19. Beltran-Aroca CM, Girela-Lopez E, Collazo-Chao E, Montero-Perez-Barquero M, Munoz-Villanueva MC. Confidentiality breaches in clinical practice: what happens in hospitals? BMC Medical Ethics 2016; 17(1): 52. DOI: 10.1186/ s12910-016-0136-y.

20. Değirmen N. Jinekoloji Ve Obstetride Beden Mahremiyeti: Kütahya Örneği. Yayımlanmamış Doktora Tezi. Osmangazi Üniversitesi Sağlık Bilimleri Enstitüsü; 2014.

21. Bahadır Yılmaz E, Ekin H. Ebelik Öğrencilerinin Hasta Mahremiyetine İlişkin Bilgi Düzeyleri. 6. Uluslararası 10. Ulusal Ebelik Öğrencileri Kongresi Tam Metin Bildiri Kitabı. 1. Baskı; 2019: 105-111.

22. Tosun H. Aksoy N. Ebelik Uygulamalarında Mahremiyet J Pro Health Res 2019; 1(1): 21-27.

23. Bijani M, Tehranineshat B, Torabizadeh C. Nurses', nursing students', and nursing instructors' perceptions of professiona lvalues: A comparative study. Nursing Ethics 2019; 26(3), 870-883. DOI: https://doi. org/10.1177/0969733017727153.

24. Martin P, Yarbrough S, Alfred D. Professional values held by baccalaureate and associate degree nursing students. J Nurs Sch 2003; 35(3): 291-296.

25. Leners, DW, Roehrs, C, Piccone, AV. Tracking the development of Professional values in under graduate nursing students. J Nurs Educ 2006; 45(12): 504-511.

26. Schank, MJ, Weis, D. Exploring commonality of Professional values among nurse educators in the United States and England. J Nurs Educ 2000; 39(1): 41.

27. Aktaș Mc, Bulduk B, Çelik D, Ensarioğlu K. Hemșirelik Öğrencilerinde Benlik Saygısı ve Empatik Düzey Arasındaki İlişkinin Çeşitli Değiş̧kenlere Göre/ Değerlendirilmesi Evaluation of Relationship Between Self Esteem and Empatic 
Level in Nursing Students According to VariousVariables. Hemşirelik Bilimi Dergisi /Journal of Nursing Science 2018; 1(3): 21-26.

28. Öner Altık H, Ek N, ve Koruklu N. Üniversite öğrencilerinin benlik saygısı düzeyi ile ilişkili bazı değişkenlerin incelenmesi. Adnan Menderes Üniversitesi Ĕ̈itim Fakültesi Eğitim Bilimleri Dergisi 2010; 1(1): 99-120.

29. Karataş Z. Eğitim fakültesi öğrencilerinin empatik becerileri ve benlik saygısı düzeylerinin incelenmesi. Mehmet Akif Ersoy Üniversitesi Ë̆itim Fakültesi Dergisi 2012; 23: 97-114.

30. Uyanık Balat G, ve Akman B. Farklı sosyo ekonomik düzeydeki lise öğrencilerinin benlik saygısı düzeylerinin incelenmesi. Frrat Üniversitesi Sosyal Bilimler Dergisi 2004; 14(2): 175-183.

31. Dinçer UHF, Öztunç G. Hemşirelik ve Ebelik Öğrencilerinin Benlik Saygısı ve Atılganlık Düzeyleri. Hacettepe Üniversitesi Hemşirelik Fakültesi Dergisi 2009; 16(2): 022-033.

32. Özkan B, Bayat M. Hemşirelik bölümü ve ebelik bölümü öğrencilerinin kendini ifade etme düzeyleri. 2.Uluslararas1 9 . Ulusal Hemşirelik Kongresi. Antalya-Türkiye, 7-11 Eylül; 2003: 100.

33. Ünsar S, İşsever H. Trakya Üniversitesi Sağlık Hizmetleri Meslek Yüksekokulu öğrencilerinin benlik saygısını etkileyen faktörlerin incelenmesi. Hemşirelik Forumu 2003; 6(1) :7-11

34. Begley CM, Glacken M. Irish nursing students' changing levels of assertiveness during their pre-registration programme. Nurse Education Today 2004; 24(7): 501-510.

Received: May 6, 2021

Accepted: May 25, 2021 